\title{
THE PARISINUS GRAECUS 2293 AS A DOCUMENT OF SCIENTIFIC ACTIVITY IN SWABIAN SICILY
}

\author{
PETER E. PORMANN ${ }^{*}$
}

\section{INTRODUCTION}

Manuscripts bear witness to the activity of the human mind in two ways. Firstly, and this is the more obvious aspect, they contain the products of intellectual endeavour, the texts, which editors strive to reproduce as faithfully as possible according to the authors' intentions. Secondly, they can tell the story of how a particular text was used and received by its readers. Parisinus graecus $2293,{ }^{1}$ the object of this study, is important in both these respects. It is the only manuscript which preserves the Arabic translation of Paul of Aegina's medical handbook or $\pi \rho \alpha \gamma \mu \alpha \tau \varepsilon i \alpha$. But it is also the only Greek-Arabic manuscript containing a non-sacral text of which we know. It is therefore an important witness for the bilingual activity of a scientific community. Yet the history of Par. gr. 2293 is shrouded in mystery because both the beginning and end of the manuscript are missing, so that there is no direct evidence as to where it was produced. In order to unravel this mystery, I shall therefore first of all carefully describe the physical condition (II), the Greek and Arabic scripts (III) and the content (IV) of the manuscript. The context of Par. gr. 2293 will be studied on two levels: I shall survey other GreekArabic manuscripts, especially those produced in Sicily, which

* I would like to thank Dr E. Savage-Smith, N. Wilson and the anonymous referree for their comments and criticism of an earlier version of this paper. Prof. D. Harlfinger deserves my gratitude for inviting me to Hamburg to discuss some of the material presented here during the Nachwuchsforum organised by his Graduiertenkolleg Textüberlieferung. It is finally my great pleasure to record my indebtness to my former teacher Prof. M. Ullmann who initiated my interest in the history of the Arabic transmission of Greek sciences and philosophy, and more specifically in Paul of Aegina.

${ }_{1}$ Or Paris, BnF, MS 2293 (fonds grec) according to the new standard for referring to manuscripts. I shall abbreviate this to Par. gr. 2293 and I adopt the practice common among Arabic palaeographers to refer to the pages of a folio as $a$ and $b$ instead of $r$ (ecto) and $v($ erso). 
testify to the bilingual activity there $(\mathrm{V}$ a), and discuss how the Greek and Arabic versions in Par. gr. 2293 relate to the textual tradition of Paul of Aegina's $\pi \rho \alpha \gamma \mu \alpha \tau \varepsilon i ́ \alpha$ (V b). On this basis I shall tackle the question where and when it was produced (VI). I already have to warn the reader at this stage that in the latter part of my paper arguments of probability will be invoked which can never be totally conclusive. I shall try to show that Par. gr. 2293 was most likely produced in Swabian Sicily where there was fervent bilingual and even trilingual activity. ${ }^{2}$ Yet, even if one should reject this location, the manuscript nonetheless sheds light on multicultural activity in the Middle Ages.

\section{PHYSICAL DESCRIPTION}

Parisinus graecus 2293 is a codex written on non-European paper (bombycinus) measuring $19.3 \times 13 \mathrm{~cm}$ with a text area of $13.3 \times 9$ $\mathrm{cm}$. The paper is unruled; its beginning and end are mutilated, i.e. there is no title or colophon. Each page (except for fols. 4b6a) consists of a Greek column on the left, and an Arabic column on the right. The paper is of brown colour, 17-24 mm thick, and fairly opaque. It is densely fibrous and has small and sometimes even large inclusions. The horizontal laid lines are very wavy, and the chain lines hardly visible. If they can be seen, they appear in groups of three. The paper has no watermarks. It is water-stained and slightly worm-eaten.

The codex has a European binding, and we find some later European notes. On the inside cover on the left: 3759 [/] Pauli AEginetae libri tres priores [/] graece arabice sine initio et fine. [/] foliorum codicis ordo et desertus [?] minime [/] aut vix dignosci possunt. By another hand: Cod. Brml. 14. Jar. On the preliminary folio: Volume de 215 feuillets. [/] Le feuillet 137 est blanc [/] 21 Mars 1885. Below that, the entry from H. Omont, Inventaire sommaire des manuscrits grecs de la Bibliothèque Nationale, Paris, 1898, p. 231 is glued: 2293. Pauli AEginetæe compendii medici libri III. priores, initio et fine mutili, græce et arabice. XIV s. Bombyc. 215 fol. (Colbert. 3759.) $P$. At the end of the manuscript on another preliminary folio we read: Pauli Aeginetae cum versione

\footnotetext{
${ }^{2}$ There is even a quadrilingual funerary inscription on display in the Castello della Zisa in Palermo, the fourth language being Hebrew.
} 
Arabica codex scriptus ante annos ut videtur 500 et ob raritatem librorum Graeco-Arabicorum maximi pretii.

The manuscript is bound in a quite erroneous way, and the confusion is amplified by the lack of catchwords. The folios have to be rearranged as follows: 1-17, 25b-18a (upside down), 26-36, 47-56, 37-46, 57-64, 127-136, 117-126, 107-116, 97-106, 87-96, $83-84,148,85-86,147,75-82,159,65-74,137-146,149-158,170-$ $179,160-169,180-211,212$ (upside down), 214, 213. At least one folio is missing between fol. 148 and fol. 85, and the same might be true between fol. 84 and fol. 148, between fol. 158 and fol. 170, or between fol. 169 and fol. 180. The edges of fol. 1 and fol. 213 (the last one in the original binding) have been repaired by gluing some different paper onto them. The same has been done with the corners of fols. 2-36.

\section{PALAEOGRAPHY}

\section{IIIa. The Greek Script}

The Greek hand of the manuscript is rather untidy, often not very consistent, and can hardly be called calligraphic. The first thing that strikes one looking at the script is the very strong modulation between large and small letters. For example, an alpha at the end of the line can be up to three times as broad as it normally is, minuscule deltas sometimes take the space of three normal letters, chis being very broad themselves protrude under the bottom line, and tau can rise to considerable height. Upsilon, too, is sometimes broadened so much as to take the space of three normal letters. The scribe often uses minuscule and majuscule forms of the same letter, e.g. a majuscule delta with a wide base stroke and the right stroke passing over bending to the left next to a standard minuscule delta. A very small majuscule eta next to a quite large minuscule one is characteristic for this script, as well as the predominance of majuscule kappa often in ligature with the following letter. $P i$ generally occurs in its minuscule shape, i.e. in the form of the two closed circles with a top horizontal stroke, but majuscule $p i$ is occasionally found in our manuscript. While the standard minuscule beta is much more common, we sometimes see a majuscule beta with 
the lower circle slightly bigger than the upper one. The scribe uses a number of ligatures and abbreviations, none of which point to any specific origin. On the other hand, they fit in well with scribal practice in Southern Italy or Sicily in the 12th and 13 th century.

The fact that the manuscript combines both older and younger writing styles is illustrated by the use of the breathings. They are normally indicated in their more archaic form of half an eta $\left(r^{-1}\right)$, but we sometimes find the round form (' ') as well. This as well as the other features mentioned rule out an early date for the manuscript. The accents are occasionally written on the last consonant of a word rather than on the vowel to which they belong, and this is an Italo-Greek feature. So although the script does not have the hallmarks of Southern Italy, it contains nonetheless at least one feature which might point into this direction. This tendency is confirmed by the analysis of the Arabic script.

\section{IIb. The Arabic script}

The Arabic text in the manuscript is written in a careful nash with a high degree of consistency. The scribe often puts the diacritical dots, and occasionally even vocalizes the text. Under the $\left.h \bar{a}^{\prime}{ }_{\tau}\right)$ he often puts a minuscule $h \bar{a}^{\prime}$ to indicate absence of dots, i.e. to distinguish it from hy $\bar{a}^{\prime}(\dot{\gamma})$ and ğim (ج), but he omits this for 'ayn. The $r \bar{a}$ ' often has a small caron over it, again to indicate absence of dots. The alif is sometimes written with a top left serif, and the ligatures läm-alif and alif-läm-alif are standard. A $h \bar{a}^{\prime}$ with a down stroke is used for انتـ i.e. finis, reproduced here by $*$.

Since the general appearance of the script is nash, it is very hard to date or locate it on purely palaeographic grounds. But there are a number of features which are quite peculiar to this script, and which deviate from the standard nash. The most striking characteristic is the medio-kāf $(\Omega)$ which is written in a nearly kufic manner. The scribe starts from the top, tracing a stroke nearly perpendicular to the base line, before he moves to the right to trace the belly of the letter. Sometimes the top stroke of initial $k a \bar{f}$ is missing (e.g. fol. 60b11 ثقل الركـبـتين); this is 
typical for many manuscripts before the forteenth century which do not come from the Islamic East. Likewise the șâd (ص) and $d \bar{a} d$ (ض) are peculiar because of the lack of the little hook ("the tooth") at the left with which they are normally written in nash. This last feature is typical for the Magribi i script. ${ }^{3}$ The already mentioned $h \bar{a}$ ' (etc.) has a very angular shape. So as with the Greek script there are no striking features which would allow the palaeographer to locate the manuscript precisely, yet at least one aspect seems to point to the Islamic West rather than the East.

\section{CONTENTS OF PAR. GR. 2293}

Parisinus Graecus contains fragments of the first three books of Paul of Aegina's $\pi \rho \alpha \gamma \mu \alpha \tau \varepsilon i \alpha$ of which the Greek text has been edited by Heiberg. ${ }^{4}$ Yet even beyond the fact that the manuscript has been bound in a extremely erroneous order, it offers a number of problems and peculiarities that are quite unmatched in other medical manuscripts. Apart from fols. 4b-6a which I will discuss below, the Greek text is written in the left, and the Arabic text in the right column. The text begins on fol. 1a with the list of contents for the first book of the $\pi \rho \alpha \gamma \mu \alpha \tau \varepsilon^{i} \alpha$, and runs as follows (the beginning of the right column is hardly legible):

$\bar{\imath} \bar{\gamma} \pi \varepsilon \rho \grave{~ c ı \rho \jmath \alpha ́ c \varepsilon \omega c ~}$

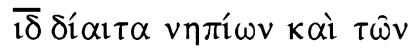

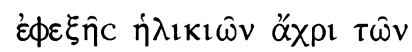

$$
\pi \alpha \rho \alpha \kappa \mu \alpha \zeta o ́ v \tau \omega \nu
$$

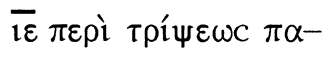

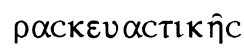

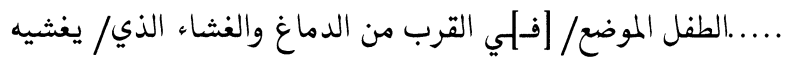

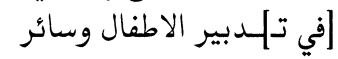

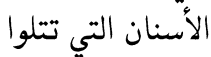

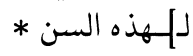
في الدلك المُعِّ للرياضة

Translation of the Arabic: $13 \ldots$ of the child. The place/ in the vicinity of the brain [?]. The membrane/ which covers it./ 14 On the diet of children and other/ age-groups following/ this age./ 15 On the massage preparing for exercise.

This table of contents continues until fol. $4 \mathrm{a}-3$ - ult.:

$\overline{c \theta} \Pi \varepsilon \rho \grave{i} \kappa \alpha \tau \alpha \phi о \rho \alpha \hat{c}$

${ }^{3}$ Cf. N. van den Boogert, "Some notes on the Maghribi script", Manuscripts of the Middle East, 4 (1989): 30-43, p. 37.

${ }^{4}$ Paulus Aegineta, CMG IX 1.2 (Lipsiae et Berolini, 1921/1924). 


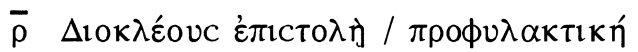
رسالة ديوقلاوس

Translation of the Arabic: 99 On lethargy./ 100 Diocles' epistle.

The rest of the page (approximately half of it) is left empty. On the verso of the same folio we find the beginning of a chapter on medical measures only in Greek, i.e. the scribe does not arrange

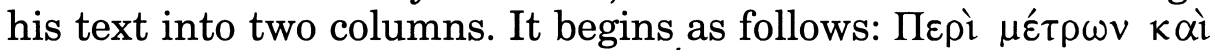

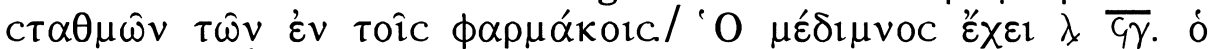

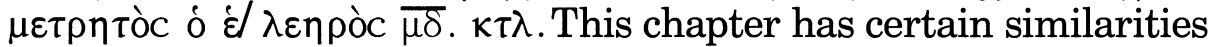
to a Pseudo-Galenic metrological text, ${ }^{5}$ but it is not found among the work of Paul of Aegina. At the beginning of fol. 5b this metrological chapter ends, and a new one entitled For the Bone Which is Swallowed and Stuck in the Throat begins. I will transcribe the whole chapter, since it is not found in any of Paul of Aegina's works nor could I locate it in any other classical medical text (fol. $5 \mathrm{~b} 4 \mathrm{ff}$.):

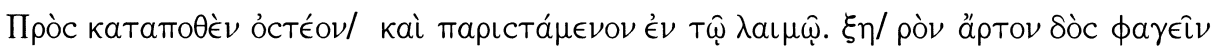

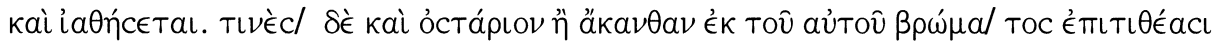

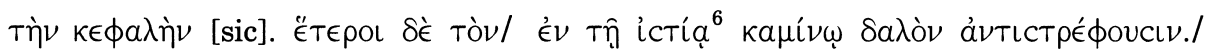

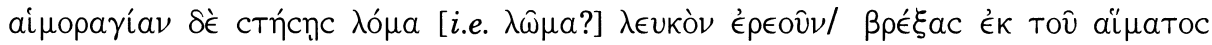

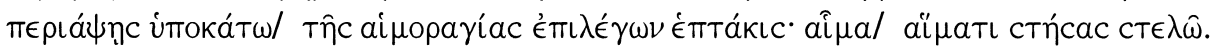

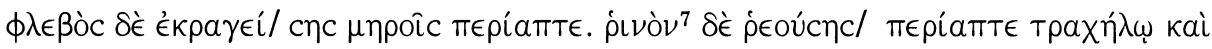

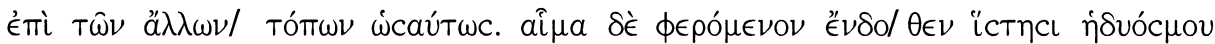

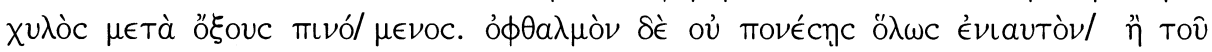

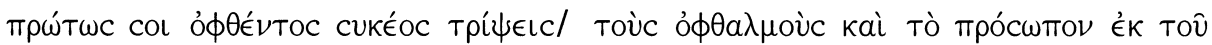

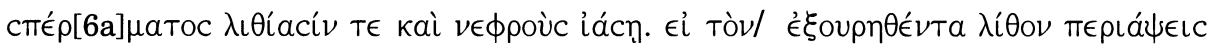

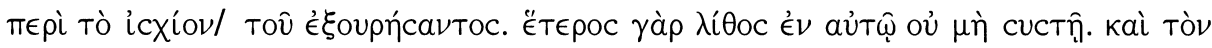

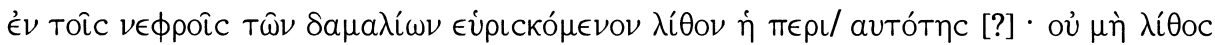

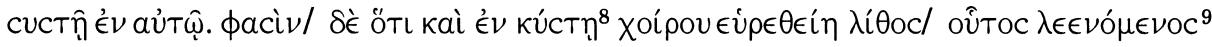

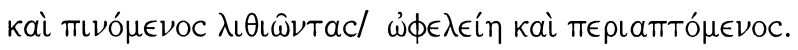

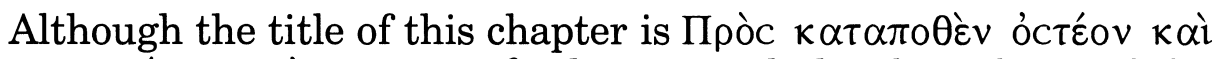

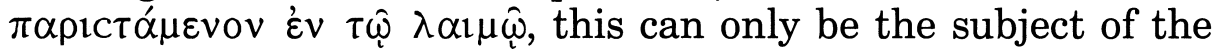

${ }^{5}$ Cf. Ps.-Galen, De metris (Kühn XIX end).

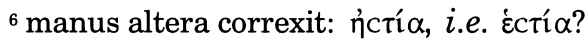

${ }^{7}$ manus altera correxit: $\dot{\rho} \imath \hat{\omega} v$.

${ }^{8}$ manus altera correxit: $\kappa u ́ c \tau \varepsilon 1$.

${ }^{9}$ manus altera correxit: $\lambda \varepsilon \alpha$ เvó $\mu \varepsilon v o c$. 
beginning of this excerpt, since later, other matters such as nose bleeding and the disease of the kidney stone are discussed. Approximately half of fol. 6 a has been left blank by the original scribe, yet a later (Renaissance?) hand has added: 'A $\rho \times \hat{\eta} \tau \hat{\eta} c$

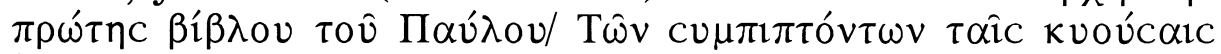

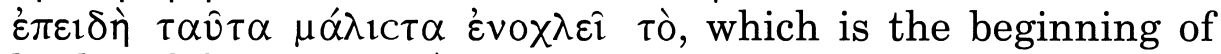
book I of the $\pi \rho \alpha \gamma \mu \alpha \tau \varepsilon i \alpha$.

At the next few folia something very characteristic for this bilingual manuscript occurs. Instead of choosing chapters of interest and copying them completely, the scribe of Parisinus graecus 2293 copies only words or single sentences taking them out of their context and thus rendering them practically useless for purely medical purposes. To give an illustration of this procedure I shall transcribe the folia $6 \mathrm{~b}$ and $7 \mathrm{a}$ :

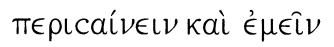

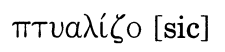

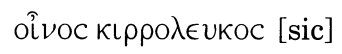

ápнótтoucl

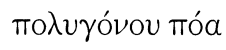

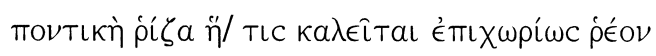

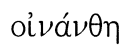

[

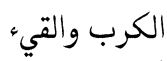

أبزق أبرو

[cuvp] víov

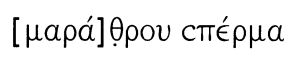

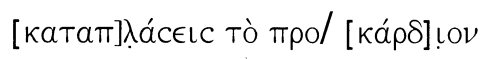

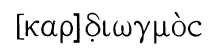

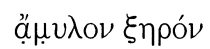

$[K\llcorner\mu \omega \lambda] i ́ a$

الشراب الخوصي يوافقهم

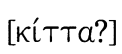

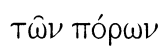
برشياندارحا وهو عصا/ الراعي رواند

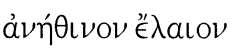

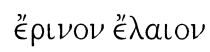

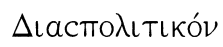

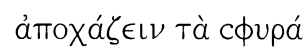

ó Sè $\phi \lambda \epsilon \gamma \mu \omega ́ \delta \eta c$

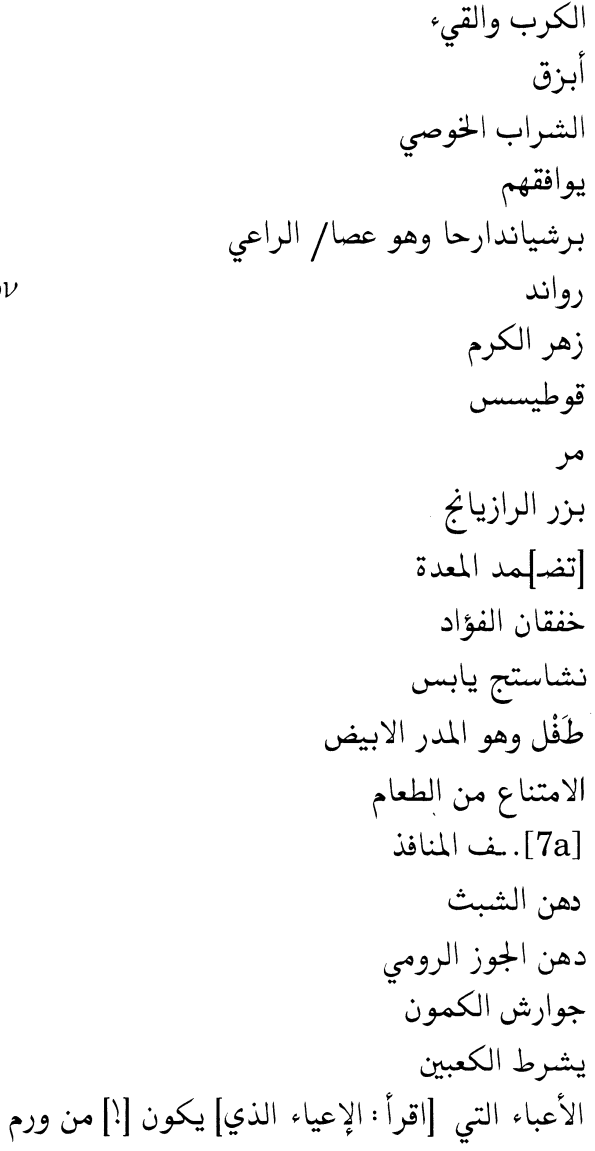


aủтó $\mu$ aтос ко́тос

$\lambda \iota \pi \circ \theta v \mu \omega \hat{~}$

[manus altera: Síaıta $\gamma \in \rho o ́ v T \omega \nu]$

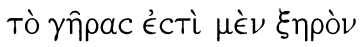

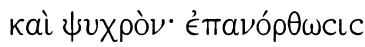

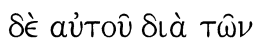

$\theta \in \rho \mu a \iota \nu o ́ v T \omega \nu$ каì vं

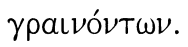

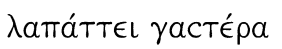

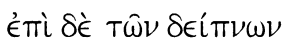

$\tau \omega \hat{\nu} \in \dot{X} \times \cup \mu \circ \alpha^{\top} \tau \nu$

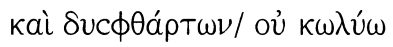

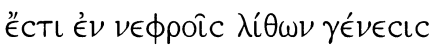

$$
\text { يغشى عليه فمتى كان حدوثه من غير سبب }
$$

[in margine manus altera: في تدبير المشايخ]

$$
\begin{aligned}
& \text { الشيخوخة هي حال } \\
& \text { باردة يابسة } \\
& \text { وعلاجها يكون يابسة } \\
& \text { بالأشياء التي ترطب ليك الأون } \\
& \text { * مع الاثياء التي تسخن } \\
& \text { يلين المعدة المياء } \\
& \text { فأما العشى فليست [اقرَا : فَلَستُتُ] }
\end{aligned}
$$

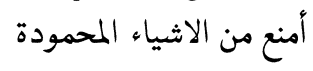

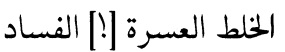

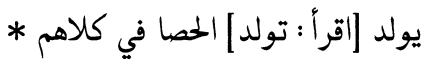

Translation of the Arabic: [6b] Anxiety and vomiting/ I split/ "Palmleaf-like" wine/ It is suitable for them/ Baršiyān dārhāa [pers. for shepherd's staff] i.e. shepherd's/ staff ${ }^{10} /$ Rhubarb/ Grapevine flowers/ Qütīsus ${ }^{11}$ / Myrrh/ Fennel seeds/ You bandage the stomach/ Palpitation of the heart/ Dry starch/ Potter's clay (tafl) i.e. white clay/Abstinence from food//[7a] ... of the channels/ Oil of dill/ Oil of Roman nut/ An electuary made of cumin/He tears the ankles/ The tiredness that arises from an inflam-/mation, and their/ occurrence is without a [specific] cause/ He loses consciousness/[In the margin: The regimen of old men]/ Old age is a state/ cold and dry/ that is treated/ by things that moisten/ along with things that warm./ It soothes the stomach/ As to dinner I do not/ prohibit things of good/ mixture and that decay with difficulty/ Generation of stones in the kidneys.

These two pages can be used to illustrate a number of features typical for this manuscript. Often the Greek is - as already mentioned - taken out of its context and put in the basic form, i.e. fol. $6 \mathrm{~b} 5 \pi 0 \lambda$ uүóvov $\pi$ ó $\alpha$ is taken from the sentence: $\dot{\omega} \mathrm{c} \delta \grave{\varepsilon}$

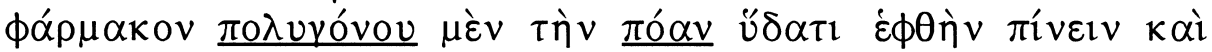

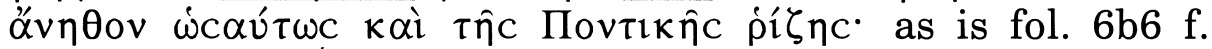

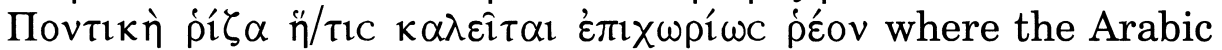
translator does not bother to render the relative clause and just

${ }^{10}$ Knot weed, a species of polygonum, is meant here.

11 The Arabs did not know how to translate kútıcoc (tree medick, Medicago arborea) and just translitterated it as qüțīs or qüțisus. Cf. Dietrich, Diosc. Triumph. IV 101. 
says روانس (rhubarb). This gives this compilation rather the appearance of a bilingual Greek-Arabic glossary. But on other occasions the scribe will copy a whole sentence from the Greek and put next to it its Arabic equivalent as in fol. $7 \mathrm{a} 9$ ff. (Tò $\gamma \tilde{\eta} \rho \alpha \mathrm{c} \kappa \tau \lambda$.).

In the whole of book one a later Arabic hand in a different ink has added the titles of the chapters in the margin, as for example here with في تدبير المشايخ On the regimen of old men. From this it can be concluded that at least for some time the manuscript must have been used with a full copy of the first three books, since the sometimes fragmentary nature of the excerpts hardly allows the reader to know from which original chapter they are

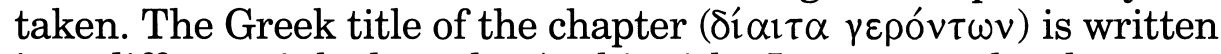
in a different ink than the Arabic title. It seems to be the same hand which wrote the few words on the bottom of fol. 6a. But as far as I can see this is the only title that this hand has added. If we compare the excerpts on fol. $7 \mathrm{a}$ with the original Greek, we see that there are lacunae of considerable length at certain points. Between $\tau \hat{\omega} v \pi$ ó $\rho \omega v$ in line one and $\alpha v \eta^{\prime} \theta 1 v 0 v$ है $\lambda \alpha 10 v$ in line two, there are eleven lines in Heiberg's edition (I, p. 18,1.12). The scribe goes to great length in order to facilitate the comparison between the Greek and the Arabic text. Sometimes he needs more space for the Greek and leaves a line or two in the right column empty, so that the Greek and the Arabic column run perfectly parallel, and sometimes the Arabic is longer, and he leaves out some space in the Greek column. For this reason the number of lines in the two columns can be different on the same page.

But it would be wrong to think that the scribe is always so selective. There are a number of complete chapters as for example I 49, 50 and 72. The longest and most important is I 100, the

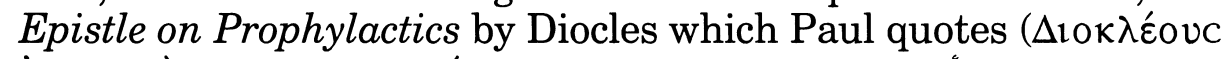

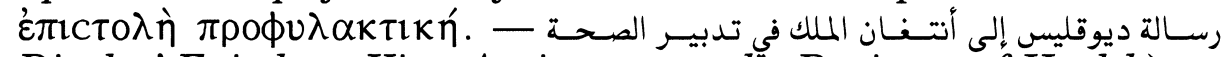
Diocles' Epistle to King Antigonus on the Regimen of Health) on fols. 57a1-64a ult. (gr.)/64a9 (arab.). ${ }^{12}$

With this chapter we come to the end of the first book, and to a very interesting folio that might shed some light on the origin

12 This is fragment no. 183a in Ph. van der Eijk's new collection of fragments by Diocles: Diocles of Carystus, 2 vols. (Leiden, 2000-1); see his commentary for an ample discussion of the authenticity of this fragment. 
of the manuscript. The Greek and the Arabic column do not as usually run completely parallel at the end of chapter I 100. In this chapter there are titles for the subsections in dark red ink which do not occur elsewhere. The Greek has the last sentence

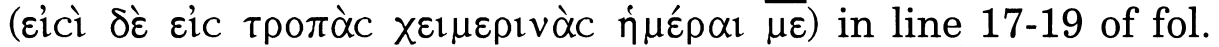
64a, while the corresponding Arabic is eleven lines up in 7-9 وجملة الأيام من هذا الوقت إلى انقلاب [!] الشتويل خمسة وأربعون يوما The sum of the days from this time until the winter solstice is forty-five days). The scribe had thus some space left in the Arabic column which he filled with a recipe or صفـة as it is noted in the margin by the same hand giving the titles of the subsections. He uses lines 10-21 of the right column and two complete line of the fol. $64 \mathrm{~b}$. The text runs:

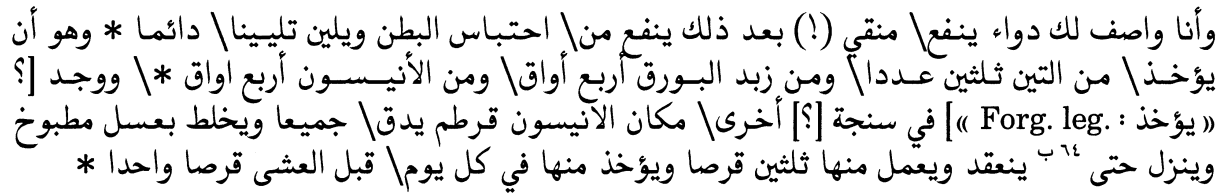

I shall describe for you a useful, cleansing agent that helps after this against constipation and brings lasting relief. I.e. take thirty figs, four ounces of borax butter, and four ounces of aniseed. Unite everything in one sanğa. ${ }^{13}$ Instead of aniseed [you can use] safflower. Pulverize everything, and mix it with cooked honey, and let it settle until it thickens. Then make from it thirty suppositories, and one of these suppository should be administered before dinner every day.

The rest of fol. 64b was originally left empty, but there are a number of readers' notes by later hands:

[there lines nearly completely faded then:]

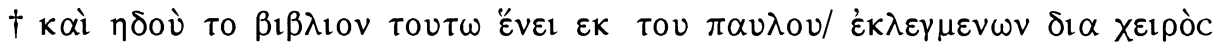

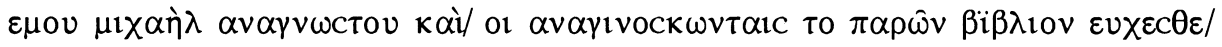

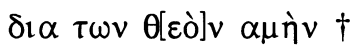

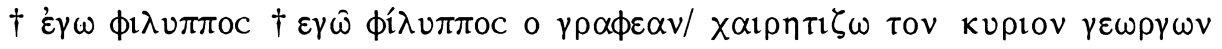

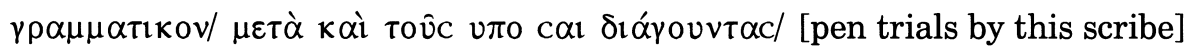

The spelling and the grammar of these lines is obviously very pour. The hand itself looks quite different, and is most likely of

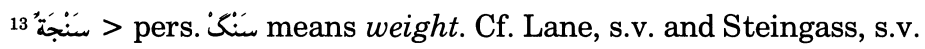


later date (14th or even 15 th century). The note probably means:

And see this book is here [?] of things selected from Paul/ by my hand, [of me] Michael the reader, and/ may the readers of the present book pray for (him)/ through God. Amen.

I, Phillip, I, Phillip, the scribe,/ greet George, the grammarian/ along with those who live under you[r command].

The names George, Phillip, and Michael being extremely common, it is hard to make out who the authors of these lines were. Yet since they seem to be a later addition, this should not concern us too much when trying to determine the origin of the manuscript.

As already mentioned, the manuscript has been bound incorrectly, and after fol. 64 fol. 127 follows with the list of contents of book two:

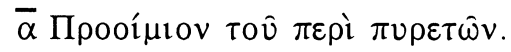

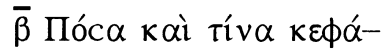

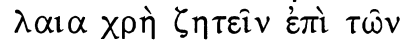

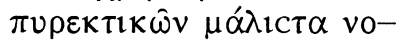

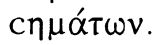

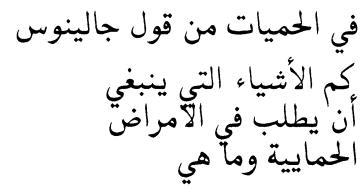

Translation of the Arabic: About fevers according to Galen./ How many things need to be/ considered as regards diseases/ which are feverish, and what are they?

In book two we do not find the Arabic titles of the chapters by a second hand as in book one, but occasionally they are written in Greek by the main scribe. For example on fol. 122a in the top margin, the main scribe has added in smaller script the title of

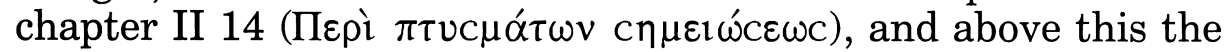
Arabic title (في دلالات البـزاق) On the signs of saliva) is written by the same hand as the main Arabic text. On fol. 110b -4 a chapter

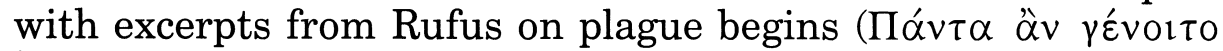
$\grave{\varepsilon} v / \lambda$ o $\mu \hat{\omega} \tau \dot{\alpha} \delta \varepsilon \imath v o ́ \tau \alpha \tau \alpha \kappa \tau \lambda$.) which is rendered in the Arabic as

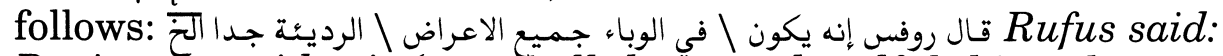
During the epidemic (waba $\overline{\text { ) }}$ all the most dreadful things happen etc. In the left margin the title of this chapter is added: 'Ek $\tau \hat{\omega} v$ 'Poú申ov, probably by the same hand, only in smaller script.

On fol. 90a book two ends (-3 - ult.):

$\lambda_{1} \theta \alpha \dot{\alpha} \rho \gamma u p o v$

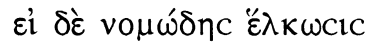

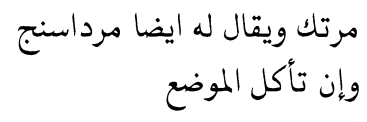


घín * وصار جرحا

Translation of the Arabic: Litharge, also called murdāsanğ (Persian for litharge)/ When the spot festers/ and becomes an open wound.

After some very simple decoration at the top of fol. $90 \mathrm{~b}$ the third book begins with the list of contents:

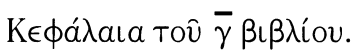
جمل ما في المقالة

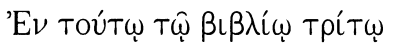
الثالثة

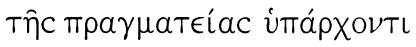

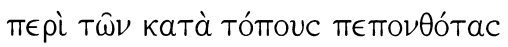

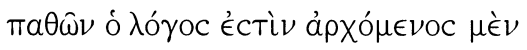

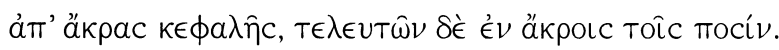

$\bar{a}$ Пఢ

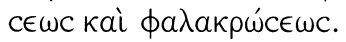

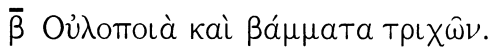

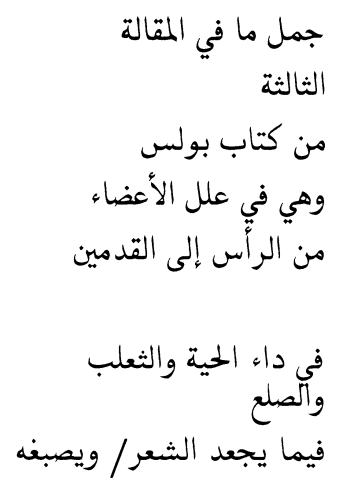

Translation of the Arabic: The contents of the/ third section/of Paul's book/ i.e. on the maladies of the parts of the body/ from the head to the feet//On alopecia, ophriasis, ${ }^{14} /$ and on baldness/ On what makes the hair curly,/ and what dyes it.

In order to be able to discuss the use and the purpose of this manuscript, I would like to give one last example as to how the scribe arranged certain chapters. Chapter III 63 deals with menstruation, and is fairly complete in the first part where more general and theoretical points are discussed, but our scribe leaves out most of the medications. The text is on fols. 199a7-200a1:

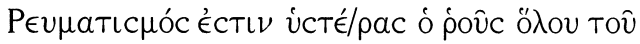

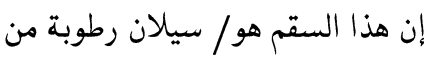
с

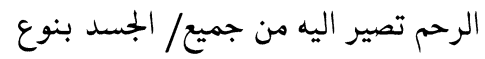

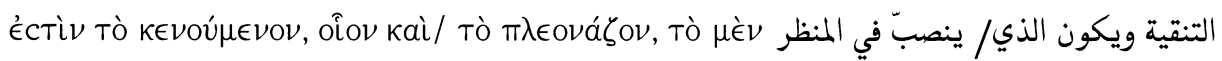

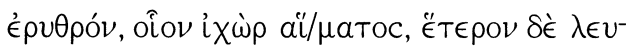

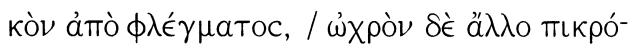

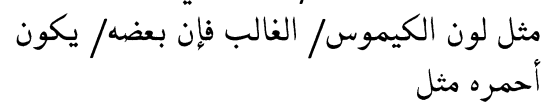
ماء الدم وبعضه/ يكون أبيض مثل البلغم

${ }^{14} D \bar{a}$ ' al-hayya (lit. the malady of the serpent) and Dä' al-ta 'lab (lit. the malady of the fox) are loan translations for $\alpha \lambda \omega \pi \varepsilon \kappa i \alpha$ and ó $\phi^{\prime} \alpha \mathrm{cic}$, two conditions characterised by the loss of hair. 


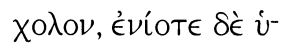
وغيره أصفر من المرة/ الصفراء وربما كان

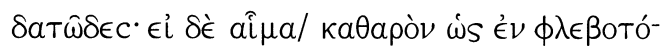

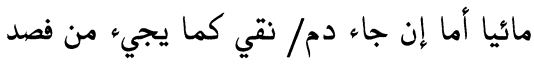

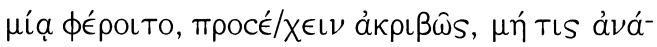

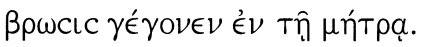

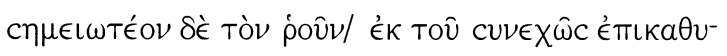

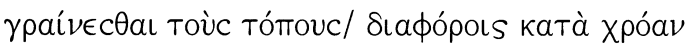

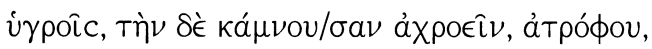

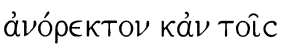

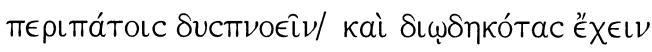
тô̂c ỏ $\phi \theta a \lambda \mu o \hat{c}$.

Tò úTò Tà $\kappa \in \lambda u ́ \phi \in l /$ Tov̂ $\beta a \lambda a ́ v o v$

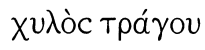

$$
\begin{aligned}
& \text { العرق فينبغي أن/ ينظر في ذلك حالا }
\end{aligned}
$$

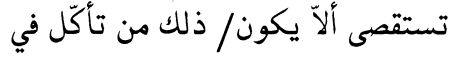

$$
\begin{aligned}
& \text { الرحم وينبغي أن/ يستدلّ على السيلان } \\
& \text { بترطيب المواضع/ ترطب متتابع برطوبات } \\
& \text { مختلفة الألوان وبأن/ العليلة تكون رديئة }
\end{aligned}
$$

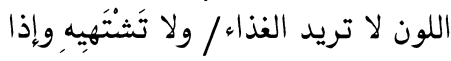

$$
\begin{aligned}
& \text { مشت يعرض لها/ عُسْر النَفَس وورم } \\
& \text { في العينين ونفخة } \\
& \text { والذي يكون تحتر قثر البلّوط } \\
& \text { * ماء الطراغوس [200a] }
\end{aligned}
$$

Translation of the Arabic: This ailment consists/ in a moist discharge from/ the womb. It [this discharge] comes to it [the womb] from all/ the body by way/ of cleansing. That which is discharged is in appearance/ similar to the colour of the predominant/ gastric juice. Some of it is red like/ bloody water, and some of it/ is white like phlegm, or else it is yellow from of the yellow/ bile, and sometimes it is [199 b] watery. If pure blood comes/ out, as it does in blood/-letting, one has to see in this a state that needs/ close attention lest it be due/ to some corruption in/ the womb. One ought to/ infer the discharge/ from the fact that places [of the body] are moistened/ successively by differently/ coloured moistures, and from the fact that/ the patient has a bad/ complection, does not seek/ or desire food; if/ she goes for a walk, she incurs/ breathing difficulties, and swellings/ in the eyes and inflation./

That which is under/ the bark of the oak/

[200 a] Juice of the trā $\dot{g} \bar{u} s$.

The last page in the original order is fol. $213 \mathrm{~b}$ of which the last four lines run as follows:

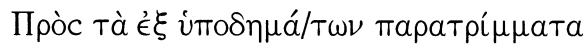

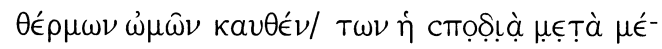

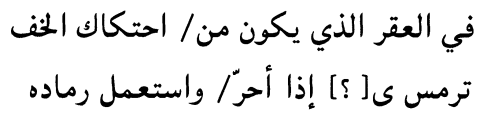

Translation of the Arabic: On the sores that occur because of/ the rubbing of a shoe/

lupine, when it is burnt and its ashes are used ...

It is clear from these last lines of our manuscript that there was at least one more page that is now missing. 


\section{Va. Other Greek-Arabic Manuscripts}

Before we can discuss the origin of Par. gr. 2293, it is necessary to place this manuscript into the context of other bilingual or even trilingual manuscripts, and to determine its position within the textual tradition of Paul of Aegina's $\pi \rho \alpha \gamma \mu \alpha \tau \varepsilon^{\prime} \alpha$. We know of only a number of Greek-Arabic manuscripts which are all, as said in the beginning of this article, of sacral content. The production and appearance of sacral manuscripts is, of course, quite different from that of non-sacral ones, yet one of the important points for my argument will be to establish that GreekArabic manuscripts were produced in Sicily. Indeed, five out of the six bilingual manuscripts that I shall mention were written in Sicily.

The one exception is the oldest bilingual Greek-Arabic manuscript we know of, the Sinaiticus arab. 116. This is a lectionary copied in 995-6 by the monk John, son of Victor of Damietta, in the Saint-Catherine monastery of Mount Sinai, ${ }^{15}$ as can be seen from the colophon on fol. 205b. ${ }^{16}$ It is written on non-western paper. The Greek script has been characterized by D. Harlfinger et $a l .{ }^{17}$ as a "[u]ntypische aufrechte (in einigen Teilen rechtsgeneigte) Spitzbogenmajuskel", and the Arabic although written in nash has many kufic elements such as the very angular $d \bar{a} l$ and $k \bar{a} f$.

The second oldest is Parisinus gr. suppl. 911, containing the gospel of St. Luke in Greek and in Arabic. ${ }^{18}$ It was produced by

15 There are a number of Greek-Arabic manuscripts among The New Finds (published by the Ministry of Culture - Mount Sinai Foundation [Athens, 1999], ISBN of the English version, not recorded in the Library of Congress: 960-85984-1-9) from the St. Catherine's Monastery on Mount Sinai, about the origins of which the catalogue is silent. They require closer attention in order to ascertain where they were produced, yet they point to bilingual activity in this community. The bilingual texts are all of sacral content, e.g. MГ 97 (table 107) and MГ 102 (t. 111) contain bilingual gospels, while M 153 (t. 140) and X 134 (t. 181) contain Greek sacral texts with Arabic marginal annotations. For a comlete list see the index on p. 285.

${ }_{16}$ Cf. G. Garitte, "Un évangéliaire grec-arabe du X $\mathrm{X}^{\mathrm{e}}$ siècle (cod. Sin. ar. 116)", in K. Treu (ed.), Studia codicologica, Texte und Untersuchungen 124 (Berlin, 1977), pp. 207-25.

${ }^{17}$ D. Harlfinger, D.R. Reinsch, J.A.M. Sonderkamp, Specimina Sinaitica. Die datierten griechischen Handschriften des Katharinen-Klosters auf dem Berge Sinai (Berlin, 1983), p. 17.

${ }_{18}$ This manuscript has been the object of a detailed study by P. Géhin, "Un 
Euphemios $\dot{\alpha} v \alpha \gamma v \omega ́ \sigma \tau \eta$ for the šammās (i.e. deacon from syr. lese John in 1043 as can be seen from the colophon. ${ }^{19}$ The Greek is written in a later form of the as de pique script typical for Southern Italy during the second half of the tenth century. The Arabic script is quite kufic, and has close affinities to the type "NS" in the classification of F. Déroche. ${ }^{20}$ But the most striking feature in the Arabic script are certain elements of Western writing style such as the Magribì. For example following the usage of the West the scribe writes $f \bar{a}$ ' (normally ف) with a dot underneath the letter, and $q \bar{a} f$ (normally 3 ) with a dot above the letter. Géhin thought that this manuscript is of Sicilian or South-Italian origin. Although neither the Arabic nor the Greek text can be related to any local Italian textual tradition (as e.g. the "Ferrar-group" for the Greek), and although the few decorations do not especially point to an Italian origin, he concluded from the Greek and the Arabic script that the manuscript was produced there.

Moving on in time we come to two Marciani graeci: no. 539, according to E. Mioni ${ }^{21}$ was produced in the middle of the 12th century, probably in Sicily. It contains a Greek-Arabic book of the four Gospels (fols. 1-265). Marcianus gr. 11 comes from the same period and area. It is trilingual (Greek, Latin, Arabic), containing the Acts of the Apostles, and the Catholic and Pauline epistles. It is interesting to note that the latter manuscript was made for liturgical use as can be seen from the marginal notes that indicate the times for the reading of the different sections.

Another trilingual manuscript which was used in liturgy is the British Library, Harley, MS 5786, ${ }^{22}$ dated to the year 1153, although the date cannot be read any more. ${ }^{23}$ M.B. Foti2 ${ }^{24}$ assumes

manuscrit bilingue grec-arabe, BnF, Supplément grec 911 (année 1043)", in F. Déroche, F. Richard, Scribes et manuscrits du Moyen-Orient (Paris, 1997), pp. 161-75.

${ }^{19}$ Cf. ibid. Fig. 1.

${ }^{20}$ Les manuscrits du Coran. Aux origines de la calligraphie coranique (=Catalogue des manuscrits arabes, $2^{\mathrm{e}}$ partie, t. I 1) (Paris, 1983), pp. 45-7.

${ }^{21}$ Bibliothecae Divi Marci Venetiarum Codices Graeci Manuscripti, 2 vols. (Rome, 1981-5), vol. II, pp. $433 \mathrm{f}$.

${ }^{22}$ Illustrations can be found in K. and S. Lake, Dated Greek Minuscule Manuscripts to the Year 1200, I-X (Boston/Mass., 1934-9), no. 80 (pl. 140-1).

${ }^{23}$ Cf. Géhin, "Un manuscrit bilingue grec-arabe", p. 175, n. 33.

24 "Il Vangelo miniato di Parma e la Biblioteca del monastero in lingua phari", Koinônia, 16 (1992): 82-3. 
that the scribe is a monk from the scriptorium of the monastery of the Holy Saviour of Messina, the taboularios George of Reggio, while $\mathrm{N}$. Wilson argued that it was produced alongside with a medical manuscript, the Vaticanus gr. 300, at the Norman court of Palermo. ${ }^{25}$ The Greek can indeed be classified as appertaining to the Reggio-style. ${ }^{26}$ The manuscript consisting of 173 folios, is of high quality vellum with very few imperfections, e.g. a hole in fol. 109 at the bottom, that has been repared. Every page has three columns, the left containing the Greek, the middle the Latin, and the right the Arabic text. I think that the same scribe first wrote the Greek and the Arabic, and then he or another hand added the Latin. That can be seen from places where he had to squeeze in the Latin between the Greek and the Arabic as on fol. 66a14 f. (ps. IL 13; the Latin in superscript here is written supra lineam in the manuscript):

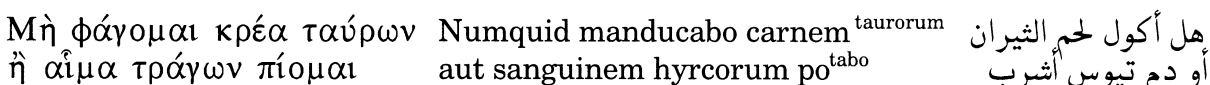

This psalter was clearly used for liturgical purposes as can be seen from a marginal note to psalm LXVIII on fol. 87a $-7--5$. The text runs:

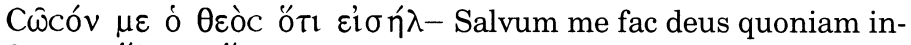

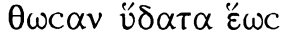
$\Psi v \times \hat{\eta} \mathrm{c} \mu \mathrm{ov}$ traverunt aquae usque ad animam meam

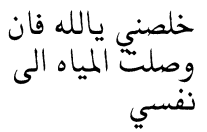

In the left margin we read: قـراة يوم الخميس بالليل Reading for Thursday night. These few lines offer another interesting point as to western influence of the Arabic script. Generally, the manuscript is written in a not too calligraphical nash, yet sometimes the scribe uses the western forms for $f \bar{a}$ ' and $q \bar{a} f$, i.e. puts one dot under the former, and one dot above the latter, as he does here in fol. $87 \mathrm{r}$ -7, -9 with نفـس He in inconsistent in this practice, e.g. in fol. $25 \mathrm{a}-3$ he writës the $f \bar{a}^{\prime}$ in فـابصـروني normally, i.e. with one dot above the letter.

${ }^{25}$ Cf. N.G. Wilson, “The Madrid Scylitzes”, Scrittura e Civiltà , 2 (1978): 209-19, where there are plates of the Vaticanus.

${ }^{26}$ Cf. P. Canart, J. Leroy, "Les manuscrits en style de Reggio", in La Paléographie grecque et byzantine, Actes du Colloque sur la paléographie grecque et byzantine (21-5 oct. 1974), (Paris, 1977), pp. 241-61. 
Of a somewhat different nature is the Greek psalter Neapolitanus gr. 20 (olim Vindob. Suppl. gr. 94) written on parchment from the eleventh century, to which one later hand added an Arabic translation in the right margin, and another a Latin version in the lower margin. This manuscript thus was not originally intended to be trilingual, but for some reason, later generations added the other translations. E. Mioni in his catalogue $^{27}$ dated the Latin script to the 13th century, but is silent about the Arabic. As to the Greek script, he says ${ }^{28}$ : "Codex procul dubio ob scripturae ductum et ornatum in Italia inferiore exaratus est." As we have already seen from the other manuscripts discussed, it was a quite common practice in Sicily or Southern Italy to produce bilingual or even trilingual manuscripts of parts of the Scriptures. So it is not unlikely that those who added the Arabic and Latin translation to this manuscript had other bilingual or trilingual codices before their eyes.

I have left undiscussed a number of later (i.e. 16th century) Greek-Arabic sacral manuscript mentioned by G. Graf ${ }^{29}$ as well as manuscripts with occasional Arabic notes in the margins. This latter type can also be found for a number of manuscripts of Paul of Aegina as already recorded by Heiberg, i.e. Par. gr. 2292 and $2207 .{ }^{30}$ But what seems evident from this brief overview is that Greek-Arabic book production took place in Sicily during the high Middle Ages. If our material bases for a statistic were not so thin, it might be possible to speak of a fashion or special interest for Greek-Arabic manuscripts in this area that began in the late 10th century and continued well into the 13th century. It is also important to note that these bilingual manuscripts were actually used. Both Harley 5786 and Marcianus gr. 11 were used for liturgical purposes. So the linguistic variety of Sicily or Southern Italy is reflected in the production and use of manuscripts.

${ }^{27}$ Catalogus codicum graecorum Bibliothecae Nationalis Neapolitanae (Indici e cataloghi, n.s. VIII), I 1 (Rome, 1992), pp. 32 f. and table IV.

${ }^{28}$ Ibid. p. 33.

${ }^{29}$ Geschichte der christlichen arabischen Literatur (=GCAL), Studi e Testi 118, 133, 146-7, 172 (Vatican, 1944 ff.), I 628.

${ }^{30}$ For a more ample discussion cf. J.L. Heiberg, "De codicibus Pauli Aeginetae observationes", in REG XXVI (1919), pp. 268-77. 


\section{Vb. PAR. GR. 2293 WITHIN THE GREEK TEXTUAL TRADITION}

Sometimes the variant readings of a manuscript can be an indication for where it was produced. This, unfortunately, is not the case for Par. gr. 2293. Heiberg remarked that Paul of Aegina's medical handbook was second in popularity only to the bible as far as copying is concerned. ${ }^{31}$ A large number of manuscripts were copied and collated during the Middle Ages, many of which survive today. Because of contamination, Heiberg was reluctant to produce a stemma of the manuscript tradition. He did recognise a number of apographa (e.g. Parisini graeci 2047, a copy of 2208 (D in Heiberg's edition); 2214, of 2206 (B); 2192, of 2191; 2209, 2215 and suppl. 924, of 2212) and divided the manuscripts used for his edition into two groups, one of which has a subgroup. Manuscripts AEa and BHM are the two subgroups of the first group while CFG form the second group. ${ }^{32} \mathrm{D}$ is sui generis, being between the two groups.

Both in his article and in the preface to his edition, ${ }^{33}$ Heiberg stresses the point that it is very difficult to know when a scribe corrects the text himself and when he relies on a different manuscript for his correction (i.e. contaminates the textual tradition). This difficulty is also apparent in the Greek text of Par. gr. 2293. To illustrate this, a list of selected, relatively significant deviations of Par. gr. 2293 from Heiberg's edition follows. The first column contains the reading Heiberg adopted (with in brackets the manuscripts displaying this reading, and sometimes alternatives), and the second column the variant in Par. gr. 2293:34

\begin{tabular}{|c|c|c|}
\hline 30,25 & ò Kpí $\omega \omega v$ & 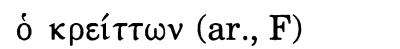 \\
\hline 33,2 & $\tau \grave{n} v\left(\mathrm{CDGKB}^{2}\right)$ & om. (AFHJ) \\
\hline 33,3 & $i \lambda \cup \omega ́ \delta \eta(\mathrm{CDGK})$ & $\dot{v} \lambda \omega \delta \delta(\mathrm{ABFH})$ \\
\hline 34,14 & $\chi \alpha \lambda \kappa \alpha v \theta^{\prime} \zeta$ $\zeta \tau \alpha(F)$ & $\chi \alpha \lambda \kappa i \zeta o v \tau \alpha(\mathrm{ABCGHJK})$ \\
\hline 36,29 & $\pi \alpha^{\prime} \nu \tau(\mathrm{ABCFGHJK})$ & $\pi \alpha ́ v \tau \alpha c(\mathrm{CO})$ \\
\hline 37,1 & $\phi \alpha \kappa \omega \hat{\omega}$ (codd.) & $\phi \alpha \rho \mu \alpha ́ \kappa \omega$ (unique) \\
\hline
\end{tabular}

31 Ibid. (n. 30), p. 268.

32 Preface, p. viii to his edition (vid. supra n. 4).

33 'De codicibus', p. 277, preface, p. viii.

${ }^{34}$ I use abbreviations Heiberg proposed in his edition (cf. conspectus codicum, p. 2), ar. denotes the Arabic translation in the facing column so far as it is possible to tell which was the underlying Greek reading. 


\begin{tabular}{|c|c|c|}
\hline 39,15 & 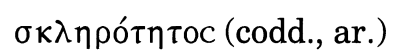 & 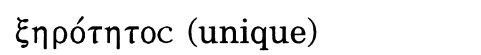 \\
\hline 42,1 & $\dddot{\eta}\left(\mathrm{ABHC}^{2}\right)$ & om. (CDFGK) \\
\hline 49,4 & 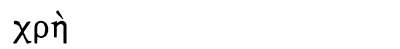 & om. (FG, mrg. K) \\
\hline 50,17 & $\varepsilon \cup ̆ \pi \varepsilon \pi \tau o c$ (codd., ar.) & 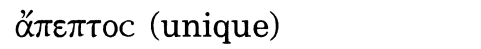 \\
\hline 51,1 & 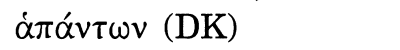 & om. (ABCFGHJ) \\
\hline 52,2 & $\dot{\rho} \alpha \phi \alpha v i ́ \delta \omega v(\mathrm{DF})$ & 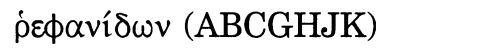 \\
\hline 52,7 & 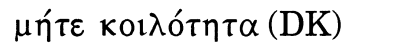 & om. $(\mathrm{ABCHJ})$ \\
\hline 56,6 & 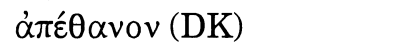 & $\theta \alpha \nu \alpha ́ c \imath \mu о \imath(\mathrm{ABCFGHJ)}$ \\
\hline 93,14 & ov่x $\left(\mathrm{DC}^{2}\right)$ & oง̂v (ABFGHJK) \\
\hline 95,6 & 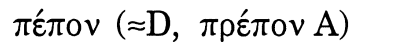 & 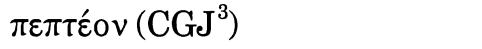 \\
\hline 109,11 & $\dot{\alpha} \kappa \rho \alpha \hat{i} \alpha(\mathrm{F})$ & 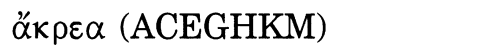 \\
\hline 110,27 & $\kappa \alpha \tau \alpha \pi \varepsilon \pi \tau \omega \kappa v i \hat{\imath} \alpha \nu(\mathrm{DF})$ & $\mu \varepsilon \tau \alpha \pi \varepsilon \pi \tau \omega \kappa \nu i ̂ \alpha \nu$ (ABCEGHK) \\
\hline 126,10 & $\kappa \alpha \kappa о \eta ́ \theta \varepsilon ı \alpha \nu(\mathrm{D})$ & $\kappa \alpha \kappa о \pi \alpha ́ \theta \varepsilon \imath \alpha \nu(\mathrm{ABCEFGHKM})$ \\
\hline 155,27 & 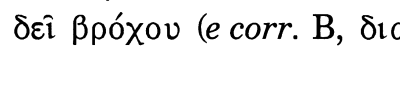 & $\begin{array}{l}\text { óxw ACDEFGHKM) } \\
\delta i \grave{\alpha} \beta \text { póxov (cum laqueo a) }\end{array}$ \\
\hline 166,8 & 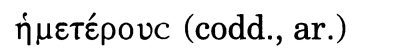 & 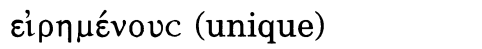 \\
\hline 184,16 & $\dot{\alpha} \rho \chi \alpha \hat{i} o r$ (codd.) & $\pi \alpha \lambda \alpha$ loì (unique) \\
\hline
\end{tabular}

This list shows that Par. gr. 2293 often has a different reading from manuscript $\mathrm{D}$, although once in 42,1 they have the same variant. Apart from that, it is impossible to say that Par. gr. 2293 belongs to any of Heiberg's groups or sub-groups. It often sides with the first group (ABEHMa) but sometimes also with the second against the first (e.g. 36, 29; 42, 1; 49, 4). This, again, illustrates the contaminated state of the tradition which makes it so difficult to establish a stemma. This is further complicated by the fact that the Arabic translation does not reflect the same textual tradition as the facing Greek. This is to say that the Arabic translation was not made directly from the Greek text. This can be seen from a number of places where the Arabic translation is based on a different Greek reading. Suffice it to give two examples. On fol. 11a -5 - paen. we read (I 41.1/I p.

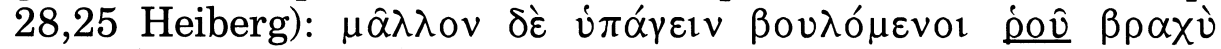

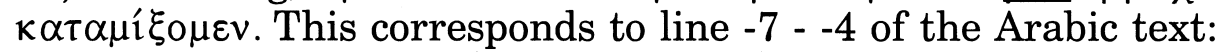

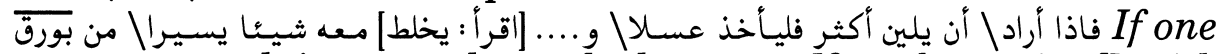
wants to sooth it more, then take honey .... [fort. leg. mixed] with a little bit of borax. So while the Greek text of the manuscript has pov i.e. sumach for which the standard Arabic translation is sumāq, the Arabic text reads bauraq which presupposes an underlying Greek vítpov. This latter reading has been adopted by Heiberg although found only in one manuscript $(F)$, while the 
former is in the manuscripts ABCHJK. On fol. 16a7-10 we have

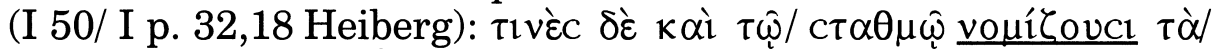

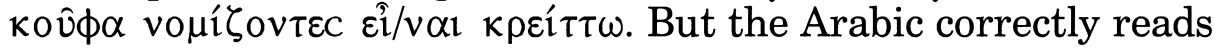

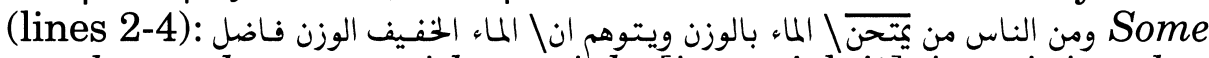
people test the water with a weight [i.e. weigh it], imagining that water of light weight is good. The Greek reading vouíovcr is

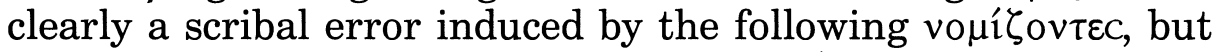
the Arabic translates the underlying $\delta \circ \kappa \iota \mu \alpha \zeta$ ovcl (shared by the rest of the manuscript tradition) which is again the better reading. I shall not try to answer the question what Greek or Syriac manuscript the original Arabic translator had at his disposal. Whether it is possible to do so given the state of the textual tradition and the fragmentary nature of Par. gr. 2293 is doubtful.

\section{THE ORIGIN AND PURPOSE OF PAR. GR. 2293}

I shall consider two fundamental questions in this last section. Firstly, what is the origin of the manuscript? Who wrote it, where was it produced, and when did this happen? Secondly, and this question cannot be entirely separated from the first one, for what purpose was it made? Who commissioned it, who used it, and what was the interest of this very peculiar product of scribal activity? Since there is no direct evidence, i.e. no colophon that can tell us all the answers to these questions, we must rely on secondary evidence in order to solve this problem.

The scribe most likely wrote both the Greek and the Arabic text, since they are written in the same ink, and since he makes a great effort to align the two versions, sometimes leaving some space in the Greek, and sometimes in the Arabic text in order to do this. As we have seen in the previous section, the Greek and the Arabic textual traditions are independent from one another. It appears that the scribe compiled our manuscript from a copy of the Greek text and an unrelated copy of the Arabic translation. His choice of the sections to copy seems to be a conscious one. $\mathrm{He}$ probably had at least a complete Arabic copy, as can be deduced from the fact that he sometimes gives a more complete Arabic text as in fol. $159 \mathrm{~b}-4$ - ult.:

$\varepsilon \phi i \alpha ́ \lambda \tau \eta \bar{c}$

$\kappa \alpha \grave{i} \pi v \imath \gamma \alpha \lambda i ́ \omega v$

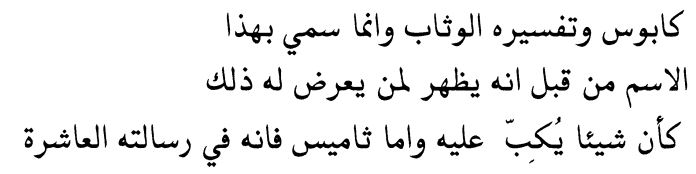

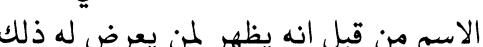
كأن 


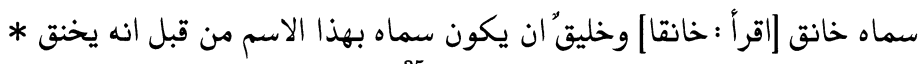
Translation of the Arabic: Nightmare $\left(k a \bar{a} b \bar{u} s^{35}\right)$. Its explanation is jumping up [witāa $b$. It is only called by this/ name, since it seems to those who suffer from it/ as if something jumped against them. As for Themison, in his tenth letter he/ named it inability to breath (häniq). It is appropriate that it be called by this name since it prevents breathing (yahnuqu).

This perfectly corresponds to the underlying Greek text, not fully quoted in our manuscript (III 15/ I p. 158,27 ff. Heiberg):

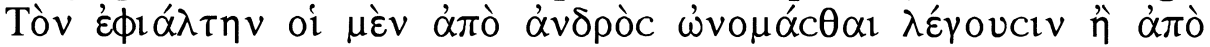

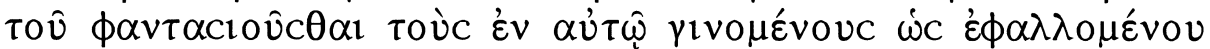

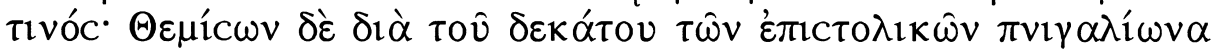

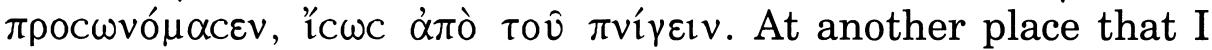
shall not discuss in detail (fol. $200 \mathrm{~b} 5 \mathrm{f}$.) the scribe has crossed out a couple of words in the Arabic that corresponded to the Greek missing in the left column, i.e. he copied something additional from the Arabic, noticed this later, and then copied the corresponding text correctly afterwards.

It is possible that the scribe had a very damaged Greek version of the first three books of the $\pi \rho \alpha \gamma \mu \alpha \tau \varepsilon i ́$, but I do not find that hypothesis convincing, since his choice of what to copy very often seems to be a conscious one. He copied the complete lists of contents of books I-III. He included the whole prophylactic epistle by Diocles as mentioned above. In his gynaecological chapters (III $60 \mathrm{ff}$. on fol. 194a paen. ff.) he normally quotes the theoretical discussion with the aetiology of the disease quite extensively while leaving out most of the therapeutical material. And, what is more, the reader who added the titles of the chapters in Arabic must have had at his disposal a complete copy of Paul of Aegina, so that it is reasonable to assume that this text was available in the milieu where the manuscript was produced.

What is the most likely area for the compilation of a very arbitrary selection of fragments from Paul of Aegina from one Greek and one Arabic source text? A selection, that is, which can only be of very limited use for the practical physician, since often either the treatment is left out, or a list of remedies is

${ }^{35}$ For an ample discussion of the concept of kābūs see M. W. Dole, Majnun: The Madman in Medieval Islamic Society (Oxford, 1992), pp. $84 \mathrm{ff}$.

${ }^{36}$ I cannot discuss here the interesting aspects of translation technique involved. The Arabic kābūs (from Syr. محصما; cf. WKAS I 20 b 33 ff.) implies pressing rather

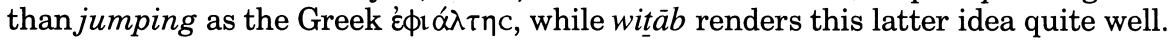


given without its context. The first indication is the bilingualism of the manuscript itself. There are a localities which provide the milieu for such a work to be undertaken. There can always be individuals who, by a curious quirk of fate, happen to be somewhere strange. Theoretically Par. gr. 2293 could have been produced, say, on Holy Island by somebody who happened to come there from Palermo and brought his own paper, but this is, of course, most unlikely, if not absurd. Again, on the basis of probability, I propose, therefore to consider places for which we actually have evidence that there was Greek-Arabic scribal activity. In each case, I will consider the arguments for or against the location, i.e. I will eliminate less likely places and finally argue for Swabian Sicily. I would like to stress, again, that this is no irrefutable proof, but I trust that Sicily is still the most likely place of production for our manuscript.

Most of the bilingual manuscripts we have reviewed above were produced in Sicily or Southern Italy, and this is therefore prima facie, the most likely location. Secondly, a number of Greek monasteries in Syria, Palestine, or Egypt could be possible candidates. Finally there is Cyprus, insula [...] inter Grecos \& Sarracenos sita,${ }^{37}$ where Greek, Arabic, and Latin culture coexisted for many centuries. Since the Greek script has none of the peculiarities of Cypriot style, this last possibility can be eliminated, although it might be possible that a Greek scribe trained elsewhere, i.e. not writing in this Cypriot style, drafted the manuscript. The second possibility has much more in its favour. Firstly the paper because of its qualities, and especially because of the chain lines in sets of three, is likely to have come from the Syro-Egyptian area. There is also, as we have seen, another bilingual manuscript, the Sinaiticus ar. 116 that indicates bilingual scribal activity. Against this hypothesis are the western elements in the Arabic script discussed above. The Greek script also suggests a date that can hardly be before the 12 th century, and more likely later. The question we have to ask is whether the milieu of 13 th or 14th century Egypt or Syria was conducive to the production of a medical, bilingual codex which served linguistic rather than

37 So the English pilgrim Willibald in his journal (in T. Tobler, A. Molinier, Itinera Hierosolymitana [Genevae, 1879], t. I, p. 288; cf. F.G. Maier, Cypern Insel am Kreuzweg der Geschichte, Urban Taschenbücher 81 [Stuttgart, 1964], esp. pp. 63 f., 86 f.). 
medical interests. A milieu, that is, in which Greek-Arabic patronage interested in non sacral texts seems not to have existed at the time. The monks there were mostly interested in sacral and liturgical texts. If the New Finds ${ }^{38}$ are anything to go by, their bilingualism was monastic: they annotated Greek holy text in Arabic, and sometimes produced bilingual editions, presumably in order that the monks, whose mother tongue was most likely Arabic, could better understand the text of the bible and the prayer books.

This is quite different in Norman or Swabian Sicily. The Normans and the Hohenstaufen promoted scientific activity. Furthermore there is ample evidence for bilingual, or even trilingual scribal activity in this area. Our manuscript is not written in one of the very typical Greek scripts of Southern Italy such as the Reggio script, nor does the Arabic script have a clearly western appearance. If it were to come from Sicily, the consistency with which the scribe writes $f \bar{a}$ ' and $q \bar{a} f$ in the eastern way, is quite unusual. As to the Greek script, we would have to assume a date when the influence of Byzantine practice in Italy had long been established. It is common knowledge that paradoxically this influence became more and more important after the Byzantines were driven out of Italy, i.e. after the end of the 11th century. Likewise P. Canart in his survey of Italo-Greek book production has shown that the use of paper and the interest in secular learning only really became frequent from the 13th century onwards. ${ }^{39}$ So if we assumed that our manuscript was produced during the 13th century, perhaps at the court of Palermo, where both the interest in medicine and in different languages was quite fervent, all the problems seem to be solved. The use of paper became more important then, and paper of rather inferior quality as that of Par. gr. 2293, destined for private usage, is in

38 Vid. supra n. 15.

${ }^{39} \mathrm{P}$. Canart, "Le livre grec en Italie méridionale sous les règnes normand et souabe: aspects matériels et sociaux", Scrittura et Civiltà, 2 (1978): 103-62. The information that can be gathered from tables II-IV are the following: Most manuscripts from the 12th-13th centuries were produced in Sicily-Calabria (XII: 50.77\%, XII-XIII $33.33 \%)$, paper is only used from the 12 th century $(0.75 \%)$ onwards, and becomes more important in later times (XII-XIII: $4.22 \%$, XIII: $5.12 \%$ ), from the 13 th century onwards there is a clear increase in the copying of secular manuscripts (XIII: $16.08 \%$, XIII-XIV: $28.88 \%$, XIV: $26.96 \%$ ). 
any case more common for secular texts. ${ }^{40}$ The Greek script follows general Byzantine rather than Italo-Greek practice which is not surprising after 150 years of intense cultural exchanges. The Arabic script, although retaining some of the Eastern features has by that time assumed the more general nash shape. Moreover, the "toothless" $s \bar{a} d / d \bar{a} d$ can be paralleled in some Sicilian GreekArabic documents of that time.$^{41}$ Finally we have two indications for a keen interest in Paul of Aegina in this area. Firstly, our oldest surviving Greek manuscript of the $\pi \rho \alpha \gamma \mu \alpha \tau \varepsilon^{\prime} \alpha$ was produced in Messina in the ninth century. ${ }^{42}$ Secondly, at that time or slightly later, a Latin translation of the third book of the $\pi \rho \alpha \gamma \mu \alpha \tau \varepsilon^{\prime} \alpha$ was prepared in Southern Italy. ${ }^{43}$

Parisinus gr. 2293 could hardly have been written for primary medical use as we have seen. I want to suggest that its main purpose was a linguistic and possibly paedagogical one. The characteristics of a glossary which it sometimes displays make it a useful tool for a student with a knowledge of one of the two languages to learn the other. A scholar already proficient in both languages could make excellent use of our manuscript to study translation techniques and might find it helpful when he himself has to translate from Arabic into Greek as has been done with al-Ǧazzār's زاد المســــــ Provisions for the Traveller and Nourishment for the Sedentary which was translated under the

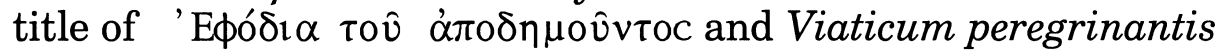

${ }^{40}$ Cf. Canart, "Le livre grec en Italie méridionale”, p. 140: “... à partir du moment où se généralise l'emploi du papier, celui-ci est utilisé davantage pour les œuvres créées et diffusées dans les milieux de spécialistes et d'érudits, aux moyens financiers limités."

${ }^{41}$ Cf. e.g. S. Cusa, I diplomi greci ed arabi di Sicilia (Palermo, 1868), vol. I, especially tav. I A. (The second volume with the translation and historical commentary never appeared).

42 Unless, that is, the inferior scriptura had been written elsewhere and then brought to Messina. These fragments are found in the underlying texts of two palimpsests, one of which is the Bruxelles Bibliothèque Royale IV 459 (cf. J. Noret, "Trente-six grands folios onciaux palimpsestes (avec un fragment inédit) de Paul d'Égine", Byzantion, 49 (1979): 307-13) and the other the cod. Messan. 2 (cf. M.B. Foti, "Frammenti di Paolo d'Egina in un manoscritto Messinese", Codices Manuscripti,

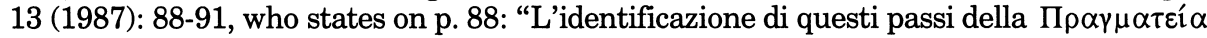
nel cod. Messan. 2, constituisce un'ultiore conferma [...] alla presenza del testo di Paolo d'Egina nell'ambiente professionale calabro-siculo.").

${ }^{43}$ Edited by J. Heiberg, Pauli Aeginetae libri tertii interpretatio Latina antiqua, (Lipsiae, 1912). 
into Greek and Latin respectively. ${ }^{44}$ It must have been produced in a community that took pleasure in the use of different languages, or just saw the need for translations to be made. A somewhat parallel case (although in many respects quite different) is the Bodleian manuscript Laud. gr. 35 discussed by G. Cavallo.. ${ }^{45}$ This Greek-Latin bilingual manuscript of the Acts written by a Greek scribe probably from Sardinia attempts to parallel the Greek and the Latin as much as possible so that according to Cavallo it was used as a dictionary rather than read as a text.

I would like to stress one point at the end of this article: the importance of an intellectual milieu for the production of books. Books are copied and annotated when people take interest in them. They serve the purpose of conveying and diffusing knowledge, and are not infrequently produced to order. If we think of the great translation movement in Baghdad in the ninth century, we see that patronage and commisioning of translations, as well as political inclinations were major factors in the promotion of bilingual or trilingual activity (in this case Greek-Syriac-Arabic). ${ }^{46}$ A similar climate of trilingual activity (Greek-Latin-Arabic) existed in Sicily and more specifically in Palermo during the late twelfth and the thirteenth century, as R. Rashed has demonstrated. ${ }^{47}$ On balance, this seems to be the most likely milieu in which Paris, BnF, MS 2293 (fonds grec) could have been produced.

${ }_{44}$ The already mentioned Vat. gr. 300 contains the Greek translation. For an overview of editions and scholarly contributions about the Provisions, see Journal of the Royal Asiatic Society (April 2001), pp. 65-9.

${ }^{45} \mathrm{G}$. Cavallo, "La cultura Italo-Greca nella produzione libraria", in G. Cavallo, Vera von Falkenhausen et al., I Bizantini in Italia (Milan, 1982), pp. 495-612, p. 503.

${ }^{46}$ Cf. D. Gutas, Greek Thought, Arabic Culture (London, 1998).

${ }^{47}$ In his chapter "Les traducteurs", in H. Bresc, G. Bresc-Bautier, Palerme 10701492. Mosaïque de peuples, nation rebelle: la naissance violente de l'identité sicilienne, (Paris, 1993), pp. 110-19. 